\title{
Soft Tissue Sarcoma of the Trunk and Extremities pT3 TNM Finding v8
}

National Cancer Institute

\section{Source}

National Cancer Institute. Soft Tissue Sarcoma of the Trunk and Extremities pT 3 TNM

Finding v8. NCI Thesaurus. Code C136687.

Soft tissue sarcoma of the trunk and extremities with tumor measuring more than $10 \mathrm{~cm}$ and less than or equal to $15 \mathrm{~cm}$ in greatest dimension. (from AJCC 8th Ed.) 